\title{
Implementasi Kebijakan Manfaat Jaminan Hari Tua di Provinsi Gorontalo
}

\author{
${ }^{1}$ Putri Wijayanti, ${ }^{2}$ Lina Miftahul Jannah \\ ${ }^{12}$ Jurusan Administrasi Publik, Fakultas Ilmu Administrasi \\ Universitas Indonesia, Depok,Indonesia \\ Email : Putri.wijayanti301@gmail.com,miftahul@ui.ac.id \\ Received: 28 Mei 2019; Revised: 5 Juni 2019; Accepted: 28 Juni 2019
}

\begin{abstract}
This writing discusses the implementation of the Old Age Insurance (JHT) benefit policy in Gorontalo Province. JHT membership in Gorontalo Province is still low. JHT is a social security needed by workers and can be enjoyed when entering retirement age. This writing uses descriptive qualitative methods with data collection techniques through the study of literature. The result of this paper is that the implementation of JHT benefits policy in Gorontalo is influenced by the content and context of the policy itself. One context is the existence of community needs which are seen as not having placed JHT as an important thing in social security for workers. This emphasizes the need for BPJS Employment to improve socialization, education and expand partnerships for better JHT sustainability.
\end{abstract}

Keywords : Old Age Insurance; Social Security

\begin{abstract}
Abstrak
Penulisan ini membahas mengenai implementasi kebijakan manfaat Jaminan Hari Tua (JHT) di Provinsi Gorontalo. Kepesertaan JHT di Provinsi Gorontalo masih rendah. JHT merupakan jaminan sosial yang diperlukan oleh tenaga kerja dan dapat dinikmati ketika memasuki usia pensiun. Penulisan ini menggunakan metode kualitatif deskriptif dengan teknik pengumpulan data melalui studi literatur. Hasil dari penulisan ini yakni implementasi kebijakan manfaat JHT di Gorontalo dipengaruhi konten dan konteks kebijakan itu sendiri. Salah satu konteksnya ialah adanya kebutuhan masyarakat yang dipandang belum menempatkan JHT sebagai hal penting dalam jaminan sosial bagi pekerja. Hal ini menekankan perlu BPJS Ketenagakerjaan untuk meningkatkan sosiallisasi, edukasi dan memerluas kemitraan untuk keberlangsungan JHT yang lebih baik
\end{abstract}

Kata kunci : Jaminan Hari Tua; Jaminan Sosial

Link DOI : http://dx.doi.org/10.31314/pjia.8.1.53-66.2019 


\section{PENDAHULUAN}

Penduduk yang bekerja di Gorontalo pada Februari 2018 mencapai 622.395 orang, hal ini menunjkan kenaikan sebesar 31.305 orang dibandingkan tahun sebelumnya (BPS, 2018). Jumlah pengangguran pada Februari 2018 sebanyak 22.551 orang mengalami penurunan sebesar 899 orang dibandingkan semester lalu (BPS,2018). Secara nasional, Data Sakernas pada bulan Februari 2018 menunjukan bahwa jumlah total tenaga kerja secara menyeluruh sebanyak 127.067.835 juta jiwa yang terdiri atas53.094.391 juta jiwa bekerja pada sektor formal dan 73.973.444 juta jiwa pada sektor informal (Sakernas, 2018).Pertumbuhan tenaga kerja baik sektor formal maupun sektor informal merupakan hal penting dalam pertumbuhan ekonomi suatu bangsa. Pekerja berhak atas pengupahan yang adil, pemenuhan jaminan sosial dan waktu istirahat.Pemerintahmemberikan perhatian pada kesejahteraan pekerja dengan melakukan telaah atas pengupahan setiap tahunnya melalui penetapan Upah Minimun Regional/Provinsi (UMR/UMP).

Setiap pekerja berhak untuk mendapatkan penghasilan yang layak, tunjangan dan jaminan sosial. Perlindungan sosial untuk pekerja di Indonesia sudah ada sejak tahun 1992 ditandai dengan terbitnya Undang-Undang Nomor 3 Tahun 1992 Tentang Jaminan Sosial Tenaga Kerja. Pada Tahun 1992, Undang-Undang Jaminan Sosial Tenaga Kerja memiliki 5 program untuk pekerja yaitu Program Jaminan Pemeliharaan Kesehatan, Program Jaminan Kecelakaan Kerja, Program JaminanKematian, Program Jaminan Hari Tua dan Program Jaminan Pensiun. Perlindungan sosial bagi pekerja ini dikelola oleh PT. Jamsostek yang merupakan perusahaan dengan profit oriented. Pada Pasal 99 ayat (1) UndangUndang Nomor 13 Tahun 2003 tentangKetenagakerjaan lebih lanjut menegaskan bahwa pekerja dan keluarganya berhak untuk mendapatkan jaminan sosial tenaga kerja. Hal ini menekankan bahwa jaminan sosial bagi tenaga kerja merupakan hal yang penting untuk melindungi pekerja dari kemungkinan yang tidak diinginkan/risiko kerja.

Undang-Undang Nomor 40 Tahun 2004 tentang Sistem Jaminan Sosial Nasional (Undang-Undang SJSN) menandai adanya reformasi dalam sistem jaminan sosial di Indonesia. Perubahan mendasar bagi jaminan sosial tenaga kerja mencakup kepesertaan untuk mendapatkan manfaat jaminan sosial tidak hanya bagi pekerja formal namun juga pekerja informal. Pemerintah menetapkan bahwa seluruh pekerja harus mengikuti jaminan sosial bagi tenaga kerja dengan kepesertaan bertahap (DJSN, 2014). Peraturan ini menegaskan bahwa Jaminan sosial tenaga kerja di Indonesia saat ini diselenggarakan oleh Badan Penyelenggaran Jaminan Sosial Ketengakaerjaan (BPJS Ketenagakerjaan) yang merupakan badan hukum publik dan menyelenggarakan 4 program yakni (i) Program Jaminan Kecelakaan Kerja (JKK), (ii) Program Jaminan Kematian (JKM), (iii) Program Jaminan Hari Tua (JHT) dan (iv) Program Jaminan Pensiun (JP).

Jaminan sosial ini memberikan perlindungan bagi pekerja saat bekerja maupun memasuki masa pensiun (pasca bekerja)dengan peruntukan perlindungan dan kesejahteraan. Jaminan Sosial menjadi hak pekerja untuk menghindari pekerja dari kemiskinan ketika terjadi hal yang tidak diinginkan/risiko. Perumus 
kebijakan SJSN mencoba meluruskan tujuan dari program JHT yang dapat memberikan manfaat besar saat pekerja memasuki usia tua atau pensiun. Peraturan pelaksana dari Undang-Undang SJSN yakni Peraturan Pemerintah Nomor 46 Tahun 2015 Tentang Penyelenggaraan Program Jaminan Hari Tua menjelaskan manfaat Program JHT berupa uang tunai yang dapat dibayarkan sekaligussaat peserta memasuki usia pensiun, meninggal dunia, atau mengalami cacat total tetap. Berdasarkan hal ini, pembayaran manfaat JHT sesuai dengan amanat UU SJSN. Peraturan Pemerintah Nomor 46 Tahun 2015 menjelaskan lebih lanjut adanya manfaat lain dari dana JHT yang dapat dicairkan yakni 10\% untuk kebutuhan persiapan pensiun dan $30 \%$ untuk perumahan dengan kepesertaan 10 tahun.

Undang-Undang SJSN dan Peraturan Pemerintah Nomor46 Tahun 2015 mendapatkan protes keras dari masyarakat karena kebijakan yang dianggap memberatkan masyarakat.Sehingga melalui Serikat Pekerja menuntut Pemerintah untuksegera merevisi Peraturan Pemerintah Tentang JHT tersebut (https//www.kompas.com, 2015).

$$
\text { Dalam penjelasan Peraturan }
$$

Pemerintah Nomor 60 Tahun 2015 tersebut tertulis bahwa pensiun termasuk pada berhenti bekerja. Hal ini menekankan bahwa manfaat program JHT dapat dicairkan ketika pekerja berhenti pekerja meskipun belum memasuki usia pensiun. Peraturan Menteri Tenaga Kerja Nomor 19 Tahun 2015 tentang Tata Cara dan Persyaratan Pembayaran Manfaat Jaminan Hari Tua yang merupakan peraturan pelaksana dari Peraturan Pemerintah Nomor 60 Tahun 2015 menjelaskan lebih jauh tentang berhenti bekerja meliputi peserta mengundurkan diri, PHK dan meninggalkan Indonesia untuk selama- dengan Undang-Undang SJSN dan telah dibahas dalam penelitian terdahulu (Acie, 2016). Kebijakan ini memberikan peningkatan signifikan pada klaim di usia produktif.Pembayaran manfaat yang dijelaskan tersebut sesuai dengan data pada Tabel 1.

Klaim dana JHT dengan alasan Peserta berhenti bekerja sebagaimana dimaksud dalam Permenaker Nomor 19 Tahun 2015 yaitu karena mengundurkan diri, PHK dan meninggalkan NKRI menjadi angka teratas dalam pembayaran manfaat pada program JHT.Ini menjadi permasalahan karena mengakibatkan berkurang atau bahkan hilangnya manfaat uang tunai yang seharusnya diterima oleh Peserta ketika memasuki usia pensiun, meninggal atau cacat total (Situmorang, 2016). Pada kenyataannya 3 hal tersebut berada pada posisi terbawah dalam pembayaran manfaat JHT. Kondisi ini membuat optimalisasi pembayaraan JHT menurun, hal ini disebabkan penarikan dana yang terus menerus bertambah menyebabkan turunnya presentase dana pengembangan yang dikembalikan kepada peserta Pergeseran filosofi JHT akibat pelaksanaan Peraturan Pemerintah Nomor 46 Tahun 2015 junto Peraturan Pemerintah Nomor 60 Tahun 2015 melalui Permenaker Nomor 19 Tahun 2015 menjadikan Jaminan Hari Tua menjadi jaminan hari tertentu ketika peserta PHK atau mengundurkan diri dan tentunya mempengaruhi penerimaan uang JHT di waktu tua.

Adapun kepesertaan jaminan sosial ketenagakerjaan untuk wilayah Gorontalo, seperti yang terlihat pada Tabel 2. Data pada Tabel menunjukan permasalahan kepesertaan dari pekerja Gorontalo yang belum optimal dalam mengikutsertakan diri ke dalam jaminan sosial ketenagakerjaan. 
Available Online at http://journal.umgo.ac.id/index.php/Publik

Publik (Jurnal Ilmu Administrasi) Vol 8 (1), Juni 2019

Tabel 1. Pembayaran Manfaat JHT Berdasarkan Jenis Klaim Semester II Tahun 2018

\begin{tabular}{|c|c|c|c|c|c|c|c|}
\hline \multirow[t]{2}{*}{ No. } & \multirow[t]{2}{*}{ Jenis Klaim } & \multicolumn{6}{|c|}{ Jumlah Kasus } \\
\hline & & Juli & Agust & Sept & Okt & Nov & Des \\
\hline 1 & $\underset{\text { Diri }}{\text { Mengundurkan }}$ & 846.795 & 971.046 & 1.096 .550 & 1.239 .640 & 1.372.042 & 1.487 .572 \\
\hline 2 & PHK & 176.132 & 202.704 & 227.998 & 255.967 & 281.681 & 303.825 \\
\hline 3 & $\begin{array}{c}\text { Meninggalkan } \\
\text { NKRI }\end{array}$ & 2.697 & 3.123 & 3.559 & 3.986 & 4.382 & 4.783 \\
\hline 4 & 5 tahun 1 bulan & 89 & 103 & 107 & 110 & 120 & 123 \\
\hline 5 & Kepesertaan $10 \mathrm{Th}$ & 17.430 & 19.865 & 22.416 & 25.437 & 28.391 & 30.702 \\
\hline 6 & Usia Pensiun & 31.225 & 36.057 & 40.738 & 45.928 & 50.398 & 54.136 \\
\hline 7 & Cacat Total Tetap & 21 & 25 & 28 & 30 & 37 & 41 \\
\hline 8 & Meninggal dunia & 16.064 & 18.672 & 21.148 & 24.056 & 26.767 & 29.064 \\
\hline 9 & Perubahan status & 2 & 2 & 2 & 2 & 2 & 2 \\
\hline & Total & 1.090 .435 & 1.251.597 & 1.412 .546 & 1.595 .156 & 1.763 .820 & 1.910 .248 \\
\hline
\end{tabular}

Sumber : Laporan BPJS Ketenagakerjaan Semester II Tahun 2018

Tabel 2 Kepesertaan Jaminan SosialKetenagakerjaan Gorontalo

\begin{tabular}{lccc}
\hline \multicolumn{1}{c}{ Segmen Peserta } & 2017 & 2018 & Juli 2019 \\
\hline JKK/JKM & & & \\
PPU & 29.832 & 64.843 & 55.513 \\
PBPU & 17.030 & 25.922 & 34.398 \\
Jakon & 89.591 & 47.388 & 53.136 \\
JHT & & & \\
PPU & 15.577 & 16.382 & 19.641 \\
PBPU & 450 & 336 & 469 \\
JP & & 16.718 & 20.110 \\
PPU & 7.471 & 8.337 & 9.756 \\
\hline Sum $:$ Olahan
\end{tabular}

Sumber : Olahan Data Primer

Berdasarkan data BPJS maka baru terdaftar sebanyak 16.718 peserta di tahun 2018 dan pada bulan Juli 2019 baru mencapai 20.110 dari 622.395 orang penduduk yang bekerja. Angka ini masih terbilang rendah. Cakupan kepesertaan jaminan sosial ketenagakerjaan di Kota Gorontalo masih rendah, kurang lebih (17\%) jika dibandingkan dengan jumlah penduduk bekerja. Kajian ini menarik karena membahas mengenai implementasi kebijakan manfaat jaminan hari tua di Gorontalo. Manfaat JHT memiliki Permasalahan yang cukup signifikan baik segi regulasi, tata kelola, dan kepatuhan para pelaksana sehingga menyebabkan manfaat JHT belum dapat optimal diterima oleh pekerja. Berdasarkan hal tersebut, maka penelitian ini menjawab pertanyaan bagaimana implementasi kebijakan jaminan hari tua di Gorontalo. 


\section{METODE PENELITIAN}

Penelitian ini menggunakan metode kualitatif untuk mengeksplorasi dan memahami makna yang oleh sejumlah individu atau sekelompok orang dianggap berasal dari masalah sosial atau kemanusiaan. Hal ini senada dengan yang diutarakan oleh Cresswell bahwa penelitian kualitatif ialah suatu upaya penggalian dan pemahaman atas makna dari yang terjadi pada indinvidu dan kelompok atas permasalahan sosial dan kemanusiaan (Cresswell 2009).

Penelitian ini merupakan jenis penelitian deskriptif karena memiliki tujuan untuk memberikan gambaran mendetail suatu keadaan yang terjadi baik baik dengan melihat situasi, latar sosial dan hubungan antara aktor sekaligus implementator yang terkait dengan implementasi kebijakan manfaat program JHT. Pengumpulan data yang dilakukan melalui wawancara mendalam dan studi literatur.

\section{HASIL DAN PEMBAHASAN}

Penelitian mengenai jaminan hari tua telah banyak dilakukan sebelumnya namun menganalisis dari sisi yuridis hukum. Hal ini seperti yang diutarakan oleh Lemek sebagai berikut: "penerapan klaim JHT mengedepankan tujuan hukum untuk memberikan rasa keadilan dan kemanfaatan untuk masyarakat tetapi tidak dapat memberikan kepastian hukum" (Lemek, 2016).

Berdasarkan hal tersebut maka kepastian hukum tidak tercapai karena peraturan pelaksana bertentangan dengan UU SJSN. Di samping itu kondisi ini menghasilkan banyaknya jumlah klaim.

Penerapan JHT di Indonesia berbeda dengan di Thailand yang menekankan bahwa JHT hanya berupa tabungan yang
Untuk kondisi ini pun Thailand belum mampu untuk mengeluarkan masyarakatnya dari kemiskinan (Chalamwong dan Meepien, 2012). Negara Philipine hingga saat ini belum dapat mencakup keseluruhan jaminan sosial pekerjanya karena kesulitan untuk mencapai sektor informal ( Ramesh, 2014).

\section{Implementasi kebijakan manfaat JHT}

Kinerja implementasi kebijakan dapat diukur tingkat keberhasilannya dari ukuran dan tujuan kebijakan yang bersifat realistis dengan sosio-kultur yang ada di level pelaksana kebijakan. Ketika ukuran dan dan sasaran kebijakan terlalu ideal (utopis), maka akan sulit direalisasikan. Untuk mengukur kinerja implementasi kebijakan tentunya menegaskan standar dan sasaran tertentu yang harus dicapai oleh para pelaksana kebijakan, kinerja kebijakan pada dasarnya merupakan penilaian atas tingkat ketercapaian standar dan sasaran tersebut (Akibu,R,2015)

Di Indonesia implementasi kebijakan manfaat dapat dikatakan telah berjalan baik namun tetap menghadapi berbagai kendala baik dari segi regulasi maupun kepatuhan dari berbagai aktor yang terlibat. PP 60 Tahun 2015 memberikan celah bagi pekerja yang mengundurkan diri untuk dapat mencairkan manfaat JHT padahal pihak Kemenaker menekankan harus dibedakan antara mengundurkan diri dan tePHK. Kondisi mengundurkan diri merupakan kondisi terencana berbeda dengan terPHK yang merupakan kondisi tidak siap bagi pekerja sehingga diperlukan dukungan untuk menghindari resiko karena kehilangan pendapatan. Selain itu, seluruh pekerja di Indonesia belum dapat menikmati manfaar JHT dikarena masih terdapat perusahaan daftar sebagian (PDS) baik dari segi program, upah dan tenaga kerja. Kondisi ini tidak pernah terlepas dari 
kebijakan JHT sebagia kebijakan publik yang telah ditetapkan.

Kebijakan publik diutarakan oleh Anderson merupakan semua yang pemerintah lakukan atau tidak dilakukan (Wahab, 2012). Hal ini senada dengan yang disampaiakn oleh Thomas Dye yang menjelaskan bahwa kebijakan publik mengenais keputusan pemerintah atas apapun untuk memilih untuk melakukan atau tidak melakukan (Dye, 2013). Dalam penelitian ini, kebijakan publik mengenai manfaat JHT merupakan tindakan yang dilakukan pemerintah untuk menyelenggarakan prinsip tabungan wajib yang ditujukan bagi pekerja yang akan memasuki usia pensiun. Penyelenggaraan JHT telah ada sejak tahun 1992 dengan terbitnya Undang-Undangan Nomor 3 tahun 1992 mengenai jaminan sosial tenaga kerja sehingga seluruh pekerja wajib memiliki Jamsostek. Pada era SJSN yang ditandai terbitnya Undang-Undang Nomor 40 Tahun 2004 tentang UndangUndangan Jaminan Sosial maka jaminan sosial ketenagakerjaan menjadi wajib bagi pekerja baik sektor formal maupun informal. Kebijakan pemberian manfaat jaminan sosial ini merupakan tindakan pemerintah untuk melindungi pekerja di Indonesia.

Tujuan yang telah disusun akan direalisasikan melalui berbagai kegiatan, bisa dalam program-program untuk mendukung tercapainya tujuan sehingga implemnetasi sebagai sebuah proses menjadi penting untuk capaian tujuan sebuah kebijakan. Dalam kebijakan manfaat JHT maka kebijakan manfaat ini diatur dalam UU SJSN yang menegaskan bahwa manfaat JHT dapat diberikan kepada peserta yang memasuki usia pensiun, cacat tetap dan meninggal dunia. UU SJSN ini dilaksanakan melalui PP
46/2015 yang menegaskan bahwa manfaat JHT dapat diberikan kepada peserta yang memasuki usia pensiun, cacat tetap dan meninggal dunia serta diberikan kelonggaran untuk mengambil setelah kepesertaan 10 tahun dengan besaran 10\% untuk persiapan pensiun dan $30 \%$ untuk kepemilikan perumahan. Kebijakan ini direspon oleh Serikat Pekerja yang keberatan dengan pengambilan manfaat JHT dengan syarat 10 tahun kepesertaan dengan anggapan waktu yang terlalu lama.

Hasil wawancara dengan Timboel Siregar selaku Koordinator BPJS Watch menyatakan bahwa pada saat ini tuntutan serikat Pekerja ialah mengembalikan kepada syarat JHT yang sebelumnya yakni merujuk pada Undang-Undang Jaminan Sosial Tenaga Kerja tahun 1992 yang menekankan pengambilan manfaat JHT pada kepesertaan 5 tahun 1 bulan. Timboel menambahkan terdapat kekurangan dalam UU SJSN karena tidak mengatur adanya kondisi tertentu dalam pengambilan manfaat JHT. Dalam UU Jamsostek 1992 maka kondisi tertentu ini yang didefinisikan pengambilan manfaat JHT dengan syarat kepesertaan 5 tahun 1 bulan. Peran dari Gabungan Serikat Buruh sangat besar dengan memberikan ancaman akan melakukan demonstrasi besar apabila Pemerintah tidak segera merevisi Peraturan Pemerintah Tentang JHT tersebut (https//www.kompas.com, 2015).

Dalam wawancara yang dilakukan terhadap Plt. Sekretaris Dewan Jaminan Sosial Nasional (DJSN), Linda Darnel menjelaskan klaim yang terjadi secara besar-besar di bulan Juli 2015 dikarenakan tidak adanya masa transisi dari kebijakan manfaat JHT itu sendiri sehingga pekerja khawatir bahwa dana JHT tidak dapat diambil kembali. Linda Darnel juga menekankan bahwa UU SJSN tidak 
Publik (Jurnal Ilmu Administrasi) Vol 8 (1), Juni 2019

memasukan pembahasan kondisi tertentu yang diartikan pengambilan manfaat JHT kepesertaan 5 tahun 1 bulan karena ingin menegaskan bahwa JHT merupakan jaminan yang diperuntukan ketika peserta memasuki usia pensiun.

Tuntutan Serikat Buruh ini kemudian direspon oleh Pemerintah dengan menerbitkan Peraturan Pemerintah Nomor 60 Tahun 2015 dan peraturan turunan di bawahnya yakni Permenaker Nomor 19 Tahun 2015. Kebijakan ini diambil pemerintah agar Serikat Pekerja berhenti melakukan demonstrasi yang tidak membuat gejolak yang berlebihan. Timboel Siregar selaku Koordinator BPJS Watch menjelaskan bahwa repson Pemerintah melebihi tuntutan pekerja sehingga pada akhirnya pekerja dapat mengambil kapanpun saat mereka terPHK dan mengundurkan diri. Timboel berpendapat bahwa kebijakan yang diambil pemerintah merupakan kebijakan populis dan akhirnya berdampak luas. Ini berdampak pada pengambilan dana JHT yang terus menerus sehingga pekerja ketika terkena PHK langsung mengambil manfat JHT berupa uang tunai ini. Ini tentunya berdampak pada sulitnya pelaksanaan pengembangan dana JHT dalam jangka waktu yang panjang sehingga pengembalian hasil pengembangan dana JHT kepada peserta tidak dapat optimal. Ahmad Ansyori sebagai Anggota DJSN dari unsur ahli menambahkan bahwa saat ini BPJS ketenagakerjaan belum memiliki target untuk pengembangan dana JHT sehingga masih terpaku dengan persentase yang dianggap aman karena masih berada di atas bunga deposito. Pada kenyataannya, BPJS ketenagakerjaan harus berinovasi untuk memberikan pengembangan dana yang baik sehingga prinsip SJSN yang ke 9 yakni memberikan sebesar-besarnya
Adanya disharmoni regulasi dari Permenaker terhadap Peraturan Pemerintah Nomor 46 Tahun 2015 dan UndangUndang SJSN ini menjadi fenomena yang lahir dari sebuah implementasi kebijakan yang melibatkan berbagai aktor dan pelaksana.

Pembahasan mengenai pergeseran filosofi manfaat JHT yang menyebabkan pergeseran filosofi JHT itu sendiri pada dasarkan tidak terlepas dari jaminan sosial bagi pekerja yang ingin diberikan oleh Pemerintah. Keputusan yang diperoleh pemerintah tidak terlepas untuk menjamin kelangsungan hidup pekerja disaat pekerja mengalami kehilangan pendapatan namun saja pengambilan keputusan tersebut dianggap kurang tepat bagi DJSN dan BPJS Watch sehingga perlu adanya telaah kembali. Implementasi Peraturan Pemerintah Nomor 46/2015 dianggap paling tepat untuk saat ini tanpa adanya PP Nomor 60 Tahun2015 dan Permenaker 2015. Implementasi kebijakan manfaat dari JHT tentunya melibatkan banyak aktor, strategi, tekanan, dan karakter dari pengambil keputusan. Untuk di wilayah Gorontalo sendiri pelaksanaan JHT tentunya sangat bergantung pada upaya bersama berbagai instansi dan masyarakat dalam melaksanakan JHT sesuai peraturan. Adanya peraturan tersebut memberikan kemudahan dan sedikit banyak menjadi peluang pada kenaikan klaim JHT itu sendiri. Data laim JHT di Provinsi Gorontalo tahun 2017-2018 dapat dilihat pada tabel 3 berikut : 
Tabel 3 Klaim JHT di Provinsi Gorontalo

2017

2018

\begin{tabular}{lclc}
\hline Kasus & \multicolumn{1}{c}{ Klaim } & \multicolumn{1}{c}{ Kasus } & \multicolumn{1}{c}{ Klaim } \\
2,624 & $15,887,053,931$ & 3,368 & $22,634,576,670$ \\
7 & $3,478,969$ & 6 & $4,499,390$ \\
\hline
\end{tabular}

Sumber : Olahan Data Primer

Sehubungan dengan permasalah lain yang diulas pada pedahulan yakni kepesertaan yang masih rendah untuk jaminan sosial ketenagakerjaan, termasuk juga untuk program JHT maka BPJS Gorontalo meningkatkan upaya untuk memperluas kepesertaan dengan melakukan kerjasama dengan pada mitra, salah satunya Pemda. Hal ini seperti yang disampaikan oleh Nelson Pomalingo dalam sebuah artikel bahwa kerjasama BPJS ketenagakerjaan dengan Pemda untuk mencover para honorer guna mendapatkan dana pensiun atau jaminan hari tua. "Ditahun 2017 ini Pemerintah lewat APBD Kabupaten Gorontalo mengalokasikan anggaran khusus untuk membayar iuran peserta BPJS Ketenagakerjaan khusus untuk tenaga honorer. Walaupun gaji mereka kecil tetapi kami ingin memastikan hari tuanya terjamin.

\section{Faktor-Faktor yang mempengaruhi Implementasi kebijakan manfaat JHT}

Grindle menyatakan bahwa implementasi kebijakan merupakan proses politik dan administrasi pemerintahan. (Nugroho, 2014). Implementasi kebijakan dapat dimulai saat sasaran telah ditetapkan, program kegiatan telah tersusun dengan baik, pendanaan telah dialokasikan untuk mencapai tujuan. Implementasi kebijakan manfaat JHt dapat mencapai tujuannya bila tindakan yang dilakukan benar dalam implementasi kebijakan terssebut. Menurut Grindle Keberhasilan suatu implementasi kebijakan publik, ditentukan oleh tingkat implementability kebijakan itu sendiri yang terdiri atas Content of Policy dan Context of Policy. Isi kebijakan (Content of policy) ini antara lain meliputi:

\section{a. Content of Policy (Isi Kebijakan)}

Kepentingan-kepentingan yang mempengaruhi Dalam implementasi kebijakan manfaat JHT terdapat kepentingan-kepentingan yang mempengaruhi yakni kepentingan pekerja, kepentingan pemberi kerja dan kepentingan pemerintah. Pekerja menginginkan adanya jaminan ketika mereka memasuki masa pensiun untuk mempersiapkan masa tuanya. Pemberi kerja membagi beban dari iuran kepada pekerja untuk menyetorkan tabungan wajib pekerja. Iuran Program JHT menurut UU SJSN dan peraturan pelaksana dibawahnya sebesar $5,7 \%$ dari gaji/upah yang didaftarkan untuk pekerja sektor formal dan informal disesuaikan dengan gaji/upah yang didaftarkan dan jenis pekerjaannya. Pada pekerja sektor formal, pemberi kerja menanggung 3,7\% dan pekerja sebesar $2 \%$. Pemerintah berkepentingan untuk memastikan pekerja Indonesia memiliki jaminan ketika mereka memasuki usia tua atau mencapai pensiun. Kepentingan ini membuat implementasi kebijakan tetap dapat berjalan karena pekerja memerlukan kesejahteraan, pengusaha memerlukan kinerja yang optimal dari pekerja yang tenang dan pemerintah memerlukan pemerintah harus mewujudkan kesejahteraan rakyatnya terlebih ketika penghasilan berkurang dalam memasuki usia tua. Hal ini tentunya akan mengurangi 
tingkat biaya ketergantungan penduduk tua kepada penduduk usia produktif.

- Tipe manfaat

Berdasarkan UU SJSN yang diturunkan melalui PP Nomor 46 Tahun 2015 manfaat JHT adalah berupa uang tunai yang diberikan kepada peserta ketika peserta memasuki usia pensiun, cacat tetap dan meninggal dunia. Ahmad Ansyori menjelaskan sebagai berikut: "setiap manusia termasuk pekerja tentunya akan mengalami masa tua sehingga dirasa perlu untuk memberikan jaminan kepada peserta ketika mereka memasui usia pensiun." Dana tersebut dapat digunakan untuk menyelesaikan hal-hal yang belum terselesaikan saat bekerja atau pun menjadi modal awal bagi pekerja memasuki dunia yang baru.

- Derajat Perubahan yang ingin dicapai

JHT telah ada sejak tahun 1992 melalui Undang-Undang Jamsostek namun di era SJSN yang ditandai dengan terbitnya Undang-Undang SJSN tahun 2004. Perubahan yang ingin diraih ialah meningkatkan kesadaran peserta akan pentingnya memiliki tabungan wajib yang dapat digunakan pada masa tua mereka sehingga persiapan memasuki dunia pensiun bisa lebih matang dan aman dengan kepesertaan wajib dengan mencakup pekerja formal dan informal. Sebelum SJSN lahir maka manfaat JHT hanya dimiliki oleh pekerja formal saja. Hal ini ditanggapi dengan adanya peningkatan kepesertaan jaminan sosial ketenagakerjaan termasuk program JHT, seperti Gambar 1. Kepesertaan program JHT meningkat dari tahun ke tahun. Sejak terbitnya Undang-Undang Nomor 40 Tahun 2004 tentang Sistem Jaminan Sosial Nasional (Undang-Undang SJSN) maka kepesertaan pada jaminan hari tua dilakukan secara bertahap dan pada tahun 2029 ditargetkan akan mencapai universal
Pada tahun 2014 peserta program JHT berjumlah 12.724.248 jiwa kemudian meningkat pada tahun 2015 menjadi 13.154.786 jiwa. Pada tahun 2016 kepesertaan program JHT mencapai 13.773.079 dan selanjutnya di tahun 2017 mencapai 14.570.283. Peningkatan kepesertaan program JHT ini juga mencakup pada pekerja sektor formal dan informal (BPJS, 2017). Dearajat perubahan dari kebijakan manfaat ini telah terlihat adanya peningkatan bagi pekerja sektor formal pada angka kepesertaan Bukan Penerima Upah (BPU) di Tabel Berdasarkan data pada Tabel 4, terlihat peningkatan BPU dari tahun 2016 sampai 2018 untuk manfaat JHT hingga mencapai 206.392 pekerja.

- Letak Pengambilan Keputusan

Kebijakan manfaat JHT ditetapkan dalam UU SJSN sehingga pengambilan keputusannya dilakukan oleh DPR kemudian peraturan pelaksananya ialah PP 46/2015 dengan inisiator Kemenaker dan perubahannya yakni PP 60/2015 serta Peraturan Menteri Ketenagakerjaan sehingga letak pengambilan keputusan dalam implementasi kebijakan manfaat JHT ada pada Presiden dan Kementerian Ketenagakerjaan RI.

Keputusan mengenai manfaat JHT ini untuk saat ini dianggap kurang tepat karena memasukan berhenti bekerja terlebih lagi mengundurkan diri. Dalam wawancaranya, Subiyanto selaku perwakilan dari Serikat Pekerja menyampaikan bahwa sebaiknya JHT dikembalikan pada UU SJSN dengan kepesertaan 10 tahun dan untuk yang terPHK sebaiknya terdapat seperti pelatihan atau unemployeement benefit untuk menopang kehidupan pekerjaa saat tidak bekerja. 


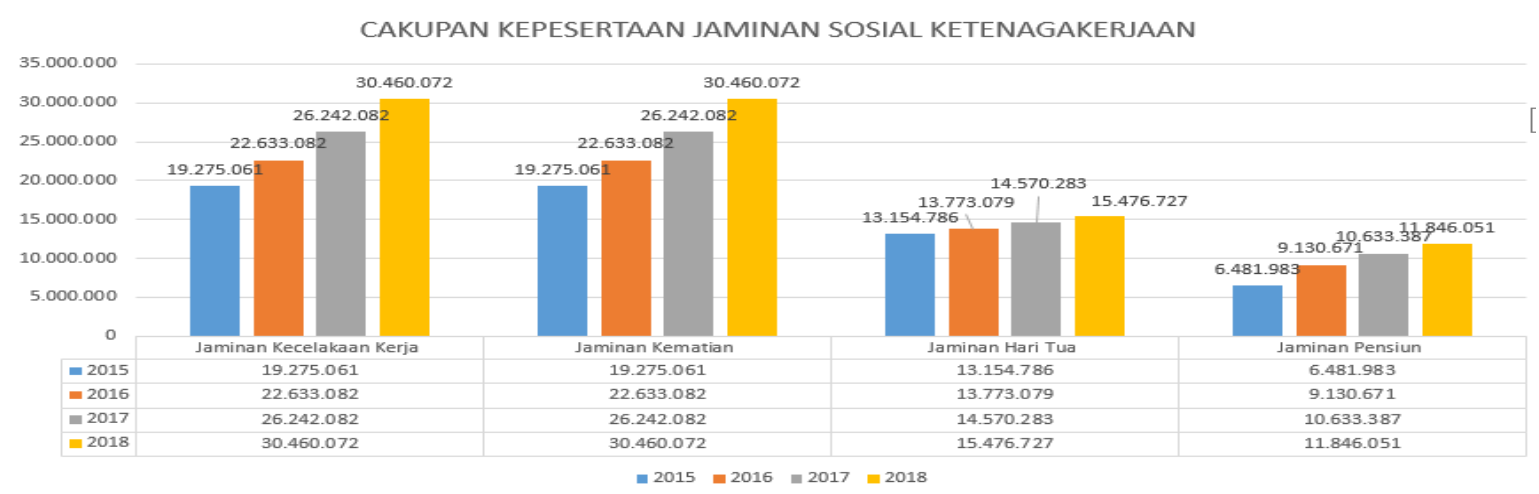

Sumber : Data Olahan dari Laporan BPJS Ketenagakaerjaan 2018

Gambar 1 Cakupan Kepesertaan Jaminan Sosial Ketenagakerjaan

Tabel 4 Segmen Kepesertaan

Jaminan Sosial Ketenagakerjaan

\begin{tabular}{|c|c|c|c|}
\hline \multicolumn{4}{|l|}{ Segmen Peserta } \\
\hline & 2016 & 2017 & 2018 \\
\hline \multicolumn{4}{|l|}{ JKK/JKM } \\
\hline PPU & 14.571 .791 & 16.068 .453 & 19.427 .150 \\
\hline BPU & 1.379 .072 & 1.714 .169 & 2.393 .022 \\
\hline Jakon & 6.682 .219 & 8.459 .410 & 8.639 .900 \\
\hline Total JKK/JKM & 22.633 .082 & 26.242.032 & 30.460 .072 \\
\hline \multicolumn{4}{|l|}{ JHT } \\
\hline PPU & 13.677 .912 & 14.427 .135 & 15.270 .335 \\
\hline PBPU & 95.167 & 143.148 & 206.392 \\
\hline Total JHT & 13.773 .079 & 14.570.283 & 15.476 .727 \\
\hline \multicolumn{4}{|l|}{ JP } \\
\hline PPU & 9.130 .671 & 10.633.387 & 11.846.051 \\
\hline
\end{tabular}

Sumber : BPJS Ketenagakerjaan, 2018

- Pelaksana Program

Pelaksana program JHT yakni BPJS

Ketenagakerjaan. Pelaksana ini memiliki pengaruh terhadap implementasi kebijakan manfaat JHT. BPJS Ketenagakerjaan sebagai penyelenggara harus dapat berinovasi untuk menarik minat sekaligus menambah kesadaran pekerja dan pemberi kerja untuk mendaftarkan diri dalam program jaminan sosial ketenagakerjaan, salah satunya JHT.
BPJS Ketenagakerjaan memiliki peran penting dalam perwujudan prinsip ke 9 dari SJSN yakni Pengelolaan Dana Jaminan Sosial Nasional dipergunakan seluruhnya untuk pengembangan program dan untuk sebesar-besarnya kepentingan peserta. Ahmad Ansyori sebagai Anggota DJSN menyampaikan bahwa peraturan saat ini hanya mengakomodir bahwa dana pengembangan JHT harus di atas Bungan deposito, sebaiknya BPJS Ketenagakerjaan memiliki target dari pengembangan dana 
program JHT dengan angka pasti misalnya 5\% dari bunga desposito atau lebih sehingga BPJS ketenagakerjaan mampu menciptakan kondisi yang optimal bagi pengembangan hasil tabungan wajib peserta. Hal ini dilakukan dengan mengedepankan prinsip kehati-hatian agar pengembangan dana dapat mencapai hasil dan optimal sehingga manfaatnya dapat terus dirasakan oleh Pekerja. Dana pengembangan ini menjadi penting karena jumlah aset JHT merupkan jumlah aset terbesar. Data aset JHT dapat dilihat pada Tabel 5

Tabel 5

Pencapaian Asset Jaminan Sosial

Ketenagakerjaan per 31 Desember 2017

\begin{tabular}{ccc}
\hline Aset & 2016 & 2017 \\
\hline JKK & 18.973 .789 .484 .9 & 24.120 .807 .511$. \\
& 03 & 671 \\
JKM & 6.362 .652 .956 .24 & 8.346 .200 .788 .7 \\
& 9 & 37 \\
JHT & 217.708 .044 .409$. & 254.208 .066 .437 \\
& 357 & .198 \\
JP & 12.195 .006 .215 .9 & 25.667 .069 .388$. \\
& 97 & 586 \\
\hline
\end{tabular}

Sumber : Data Olahan Peneliti berdasarkan

Laporan Keuangan BPJS Ketenagakerjaan, 2017

Berdasarkan data di Tabel 5 maka dapat dilihat aset terbesar terdapat pada program Jaminan Hari Tua (JHT), ini menekankan bahwa pengelolaan aset yang baik dapat bermanfaat pada pengembalian yang optimal bagi peserta. Pelaksana lain dari program adalah pekerja dan pemberi kerja. Pekerja sebagai peserta yang menerima manfaat memiliki peran penting dalam implementasi kebijakan manfaat JHT. Peserta membayar iuran JHT berdasarkan upah yang diterima. Dalam halini upah yang menjadi acuan dasar iuran ialah gaji dan tunjangan tetap sesuai yang telah ditetapkan dalam PP 46 tahun
2015 tentang Penyelenggaraan Jaminan Hari Tua. Pemberi kerja memberikan dukungan sebagai pelaksana dengan membayarkan sebagian iuran sebesar 3,7\% dari upah pekerja.

- Sumber-sumber daya

Implementasi kebijakan manfaat JHT tidak ada berhasil tanpa adanya sumber-sumber daya yang digunakan dengan baik. Sumber daya yang ada ialah kecukupan pendanaan, pemahaman, pegawai yang berkinerja baik, sistem IT yang memadai, regulasi yang baik, dan sebagainya.

\section{b. Context of Policy (Lingkungan Kebijakan)}

- Kekuasaan,kepentingan-kepentingan, dan strategi dari aktor yang terlibat (Power, Interest, and Strategy of -Actor Involved)

$$
\text { Implementasi kebijakan manfaat }
$$

JHT dipengaruhi oleh kekuasaan, kepentingan, strategi dari aktor yang terlibat. Hal ini ditandai adanya pergerakan serikat pekerja yang menuntut adanya perubahan masa kepesertaan dalam pengambilan manfaat JHT. Hasil wawancara dengan Bapak Andi Awaluddin selaku Kepala Sub Direktorat kepesertaan Jaminan Sosial, untuk mengakomodir tuntuan pekerja, berbagai kementerian, termasuk kemenaker dan Kemenkumham bersinergi untuk melakukan pembahasan sehingga dikeluarkanlah keputusan untuk merevisi PP 46 Tahun 2015. Keputusan tersebut dilakukan guna menjaga stabilitas sosial dan ekonomi. Pernyataan tersebut ditambahkan dalam implementasinya terdapat celah kepada pekerja yang mengundurkan diri dan menyebabkan usia produktif banyak yang menarik JHT. 
- Karakteristik lembaga dan rezim yang berkuasa (Institution and Regime Characteristic)

- Karakteristik lembaga dan rezim yang berkuasa (Institution and Regime Characteristic)

Karakteristik rejim yang berkuasa menjadi sangat kuat untuk mempengaruhi implementasi kebijakan manfaat JHT di Gorontalo. Pemerintah melalui Peraturan Menteri Ketenagakerjaan Nomor 19 tahun 2015 membuat keputusan bahwa manfaat JHT dapat diambil kapanpun saat pekerja berhenti kerja yang didefinisikan menjadi ter-PHK dan mengundurkan diri. Strategi pemerintah nyatanya memberikan pengaruh yang sangat signifikan terhadap implementasi kebijakan manfaat JHT itu sendiri baik dari segi regulasi, maupun tata kelola bagi pengembangan dana JHT.

- Tingkat kepatuhan dan adanya respon dari pelaksana (Compliance and Responsiveness).

Berdasarkan Pasal 11 UndangUndang Nomor 24 tahun 2011 tentang BPJS, wewenang BPJS salah satunya ialah melakukan pengawasan dan pemeriksaan atas kepatuhan Peserta dan Pemberi Kerja dalam memenuhi kewajibannya sesuai dengan ketentuan peraturan perundangundangan jaminan sosial nasional. Pemberi kerja masih banyak yang melakukan Perusahaan Daftar Sebagian (PDS) baik upah, program dan tenaga kerja. Sesuai dengan data pada table 3.1. kepesertaan JKK/JKM jauh lebih tinggi dibandingkan JHT. Ini memperlihatkan bahwa tidak semua perusahaan mendaftarkan seluruh program kepada pekerjanya. Saat ini BPJS Ketenagakerjaan melakukan tugas dan fungsinya sesuai dengan dan menyelenggarakan

program

JHT berdasarkan kebijakan manfaat JHT yakni Permenaker Nomor 19 tahun 2015. BPJS sebagai penyelenggara mematuhi target kinerja dan merespon antusias yang tinggi dalam klaim JHT. BPJS Ketenagakerjaan memfasilitasi peserta dengan memberikan sistem online untuk setiap klaim dan pemantauan saldo JHT. Kepatuhan dan adanya respon dari BPJS ketenagakerjaan memberikan ruang tetap berjalannya implemenatasi kebijakan manfaat JHT bagi peserta.

Grindle mengemukakan padangan implmentasi kebijakan melalui satu rantai komando sehingga pemikiran bahwa implementasi top-down sangat melekat dalam faktor yang menentukan implementasi kebijakan. Rippley dan Franklin mencoba menegaskan bahwa implementasi kebijakan tidak hanya dilihat sebagai sebuah komando tetapi lebih dari itu yakni perlu adanya perhatian untuk pandangan-pandangan individu dan organisasi. Teori yang dibahas oleh Rippley dan Franklin (dalam Winarno, 2014) ini ialah Hybrid yang merupakan gabungan antara model top-down dan bottom-up dari implementasi kebijakan. Implementasi kebijakan JHT tidak dapat hanya melihat dari sisi pemerintah namun melihat cara pandang pekerja sebagai peserta. Pekerja menyadari adanya kebutuhan mencairkan dana JHT ketika ter PHK namun mereka mulai menyadari bahwa JHT yang ditempatkan menjadi Jaminan Hari Tertentu bukan merupakan kebijakan yang tepat untuk menempatkan JHT. Riplley dan Franklin melihat implementasi melalui pendekatan kepatuhan dan pendekatan faktual. Pendekatan kepatuhan melihat BPJS 
ketenagakerjaan harus mematuhi peraturan yang telah ditetapkan termasuk untuk mengumpulkan dana jaminan sosial sesuai dengan ketentuan yang berlaku. Hal ini menegaskan BPJS memiliki peran penting dalam keberhasilan implementasi manfaat JHT karena mampu mengantisipasi adanya Perusahaan Daftar Sebagiann (PDS) baik program, upah dan tenaga kerja.

Untuk pendekatan faktual yakni secara sosiologis maka pekerja memiliki kekhawatiran bukan hanya kehilangan pendapatan di saat tua namun pada usia produktif. Hal ini mengakibatkan pekerja dianggap terpaksa mencairkan manfaat JHT ketika terPHK walaupun masih dalam usia produktif. Menurut Subiyanto, perwakilan dari serikat pekerja menyampaikam bahwa jaminan sosial saat tidak bekerja atau unemployeement benefit harus ada untuk menopang pekerja yang mengalami PHK sehingga dapat membantu kehidupannya hingga dapat bekerja kembali. Ini sebaiknya tidak mengambil dari dana JHT sehingga dana JHT dapat tetap diterima oleh peserta ketika memasuki usia pensiun.

\section{PENUTUP}

\section{Kesimpulan}

Implementasi kebijakan manfaat JHT di Gorontalo yang berjalan saat ini tidak dapat terlepas dari konten dan konteks kebijakan JHT itu sendiri. Konteks pada masyarakat yang ada di Gorontalo bahwa keberadaan jaminan sosial ketenagakerjaan belum banyak dikenal oleh masyarakat. Berbeda halnya dengan jaminan sosial kesehatan yang tetelah mencapai Universal Health Coverage (UHC). Selain itu, angka klaim JHT di Gorontalo selaras angka klaim di tingkat nasional yakni mengalami peningkatan. Implementasi kebijakan manfaat JHT dipengaruhi baik dari isi kebijakan maupun lingkungan kebijakan. Isi kebijakan mencakup kepentingan, jenis manfaat, perubahan yang diinginkan, letak pengambilan keputusan, pelaksana program, dan sumber daya. Selain itu, lingkungan kebijakan yang mendukung adanya pergeseran filosofi JHT membuat implementasi kebijakan JHT tidak hanya menjadi jaminan ketika tua namun dapat menjadi jaminan ketika kehilangan penghasilan dengan konsekuensi yang sangat besar yakni pesertatidak lagi memiliki dana di hari tuanya kelak. Kepatuhan dan faktual menjadi hal yang juga mempengaruhi implementasi kebijakan manfaat JHT namun sudah sebaiknya pemerintah memiliki jalan keluar yang lebih baik agar JHT tetap diperuntukan untuk pekerja yang memasuki usia pensiun.

\section{Saran}

1. Pemerintah perlu mengembalikan JHT kepada filosofi yang awal sehingga Peraturan Pemerintah Nomor 60 Tahun 2015 perlu dicabut untuk mewujudkan sinkronisasi regulasi.

2. Pemerintah dapat memper timbangkan adanya kebijakan untuk pekerja yang terPHK dan mengundurkan diri secara terpisah dari JHT sehingga adanya kebijakan unemployeement benefit untuk memberikan perlindungan saat pekerja kehilangan pendapatan dan pemberian pelatihan/softskill untuk kebutuhan SDM Indonesia dalam menghadapi uncertainty world.

3. BPJS Ketenagakerjaan perlu melakukan upaya yang inovatif dan kreatif untuk dapat mengembangkan Manfaat Layanan Tambahan (MLT) sehingga mampu menarik minat pekerja untuk menjadi peserta. 
4. BPJS Ketenagakerjaan perlu lebih tegas dalam melaksanakan kewenangan yakni menagih pembayaran iuran dan melakukan pengawasan dan pemeriksaan atas kepatuhan Peserta dan Pemberi Kerja dalam memenuhi kewajibannya sehingga tidak terdapat piutang.

\section{DAFTAR PUSTAKA}

Akibu, R. (2015). Implementasi Kebijakan Perizinan Penyiaran Televisi Lokal Di Provinsi Gorontalo. Publik (Jurnal Ilmu Administrasi), 4 (2), 6369.

doi:http://dx.doi.org/10.31314/pjia.4. 2.63-69.2015

Ginting, Dengo dan Kolondan. (2016). Impelementasi program jaminan sosial ketenagakerjaan di Kota Manado. Jurnal Administrasi Publik Universitas Sam Ratulangi Vol. 3 nomor 400.

Neuman, W Laurence. (2014). Social Research Methods: Qualitative and Quantitative Approaches.New York: Pearson.

Nugroho, Riant. (2014). Public Policy. Jakarta: PT. Elex Media Komputindo

Parsons, Wayne. (2014). Public Policy: Pengantar Teori dan Praktik Analisis Kebijakan. Jakarta: PT. Prenadamedia Group

Putri, Asih Eka. (2014). Paham transformasi Jaminan Sosial Indonesia. Jakarta : Friedrich-EbertStiftung

Ramesh, M. (2014). Social Protection in Indonesia and the Philippines. Journal of Southeast Asian Economies, Vol. 31, No. 1, pp. 40-56.

Rufus, Elias Samba. (2016). Pelaksanaan BPJS Ketenagakerjaann Program Jaminan Hari Tua (JHT) di PT Yogya Presisi Tehniktama Industri (YPTI) di Yogyakarta. E-journal Universitas Atmajaya Yogyakarta.
Situmorang, Chazali H. (2016). Dinamika Penyelenggaraan Jaminan Sosial Di Era SJSN. Depok : Social Security Development Institut (SSDI).

Sholiha Afif Fauziyani dan Warsono, Hadi. (2018). Analisis Kualitas Pelayanan Program Jaminan hari Tua Badan Penyelenggaraan Jaminan Sosial (BPJS) Ketenagakerjaan Cabang Ungaran. Journal Of Public Policy And Management Review Vol. 7 Nomor 4.

Suyanto, Bagong. (2010). Metode Penelitian Sosial. Jakarta: Prenada Media Group

Undang-Undang Nomor 40 Tahun 2004 Tentang Sistem Jaminan Sosial Nasional

Undang-Undang Nomor 24 Tahun 2011 Tentang Badan Penyelenggara Jaminan Sosial

Peraturan Pemerintah Nomor 46 Tahun 2015 Tentang Penyelenggaraan Jaminan Hari Tua

Peraturan Pemerintah Nomor 60 Tahun 2015 Tentang Perubahan Peraturan Pemerintah Nomor 46 Tahun 2015 Tentang Penyelenggaraan Jaminan Hari Tua

Peraturan Menteri Ketenagakerjaan Nomor 19 Tahun 2015 Tentang Tata Cara dan Persyaratan

Youngyuth Chalamwong dan Jidapa Meepien. (December 2012). Poverty dan Just Social Security In Thailand. Asean Economic Bullentin. Vol. 29, No. 3, Sustainable and Just Social Protection in Southeast Asia, pp. 230-244.

Wahab, Abdul, Solichin. (2012). Analisis Kebijakan. Jakarta: PT. Bumi Aksara

Winarno, Budi. (2014). Kebijakan Publik: Teori, Proses, dan Studi Kasus. Yogyakarta : Centre of Academic Publishing Service (CAPS) 